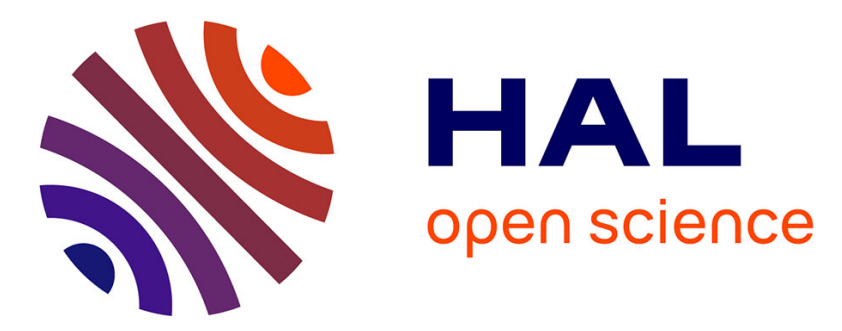

\title{
Microstructural and electrochemical characterization of laser deposited 18-10 austenitic stainless steel clad layers
}

F. Fouquet, P. Sallamand, J. Millet, A. Frenk, J. Wagniere

\section{To cite this version:}

F. Fouquet, P. Sallamand, J. Millet, A. Frenk, J. Wagniere. Microstructural and electrochemical characterization of laser deposited 18-10 austenitic stainless steel clad layers. Journal de Physique IV Proceedings, 1993, 03 (C7), pp.C7-991-C7-994. 10.1051/jp4:19937153 . jpa-00251776

\section{HAL Id: jpa-00251776 https://hal.science/jpa-00251776}

Submitted on 1 Jan 1993

HAL is a multi-disciplinary open access archive for the deposit and dissemination of scientific research documents, whether they are published or not. The documents may come from teaching and research institutions in France or abroad, or from public or private research centers.
L'archive ouverte pluridisciplinaire HAL, est destinée au dépôt et à la diffusion de documents scientifiques de niveau recherche, publiés ou non, émanant des établissements d'enseignement et de recherche français ou étrangers, des laboratoires publics ou privés. 


\title{
Microstructural and electrochemical characterization of laser deposited 18-10 austenitic stainless steel clad layers
}

\author{
F. FOUQUET, P. SALLAMAND, J.P. MILLET ${ }^{*}$, A. FRENK ${ }^{* *}$ and J.D. WAGNIERE ${ }^{* *}$
}

GEMPPM/CALFETMAT, INSA bât. 502, 69621 Villeurbanne cedex, France

* Physicochimie Industrielle, INSA bât. 401, 69621 Villeurbanne cedex, France

${ }^{*}$ Centre de Traitement des Matériaux par Laser (CTML), Ecole Polytechnique Fédérale de Lausanne (EPFL), 1015 Lausanne, Switzerland

\begin{abstract}
The present work reports on 18-10 stainless steel coatings produced by laser powder cladding technique on a mild steel. Uniform clad layers - about $600 \mu \mathrm{m}$ thick - have been produced through partially overlapping single cladding tracks. The clad layers thus obtained show excellent adherence, no cracks, few porosities and good chemical homogeneity. The microstructure is dendritic or cellular. Dentrites or cells have an austenitic structure and a small amount of $\delta$-ferrite is detected in the interdendritic areas. The corrosion resistance of the clad layers is tested by electrochemical techniques in various neutral or acidified aqueous saline media, deaerated or naturally aerated. In every case, the coatings show an excellent uniform corrosion resistance.
\end{abstract}

\section{INTRODUCTION}

In a previous work, we produced corrosion resistant coatings by laser melting of a twin nickel and chromium electrodeposit on a mild steel [1]. Surface alloys thus obtained were austenitic stainless steels with an excellent uniform corrosion resistance. Nevertheless, the laser alloying technique that requires predeposits is a very expensive method to get coatings on large surface areas. So other methods must be considered to produce such coatings. At present time, laser powder cladding is a technique frequently used to realize wear or corrosion resistant coatings on different materials $[2,3,4]$. The present work aimed to characterize the main metallurgical features of laser clad layers of type 304 austenitic steel deposited on a carbon steel. The investigated features included microstructure, compositional homogeneity, degree of dilution and corrosion behaviour.

\section{EXPERIMENTAL PROCEDURE}

The stainless steel powder used had a grain size of between 50 and $100 \mu \mathrm{m}$. The chemical composition of the powder is given in table 1 . The substrate was $0.15 \mathrm{wt} \%$ carbon steel. The samples were of parallelepiped form $\left(70 \times 35 \times 20 \mathrm{~mm}^{3}\right)$. The cladding powder was transported in pressurised argon and injected under the laser beam near the substrate surface with an injection angle, with respect to the horizontal, of $55^{\circ}$ as shown on figure 1 . The laser used was a $1.5 \mathrm{~kW}$ continuous wave $\mathrm{CO}_{2}$ laser. Laser device and processing conditions were described in more details elsewhere $[5,6]$. Uniform clad layers approximatively $600 \mu \mathrm{m}$ thick - were produced through partially overlapping single cladding tracks. The following processing parameters were used : beam diameter $2 \mathrm{~mm}$, injection nozzle diameter $2 \mathrm{~mm}$, intertrack advance $1 \mathrm{~mm}$, scanning speed $700 \mathrm{~mm} / \mathrm{min}$ and powder feeding rate $6 \mathrm{~g} / \mathrm{min}$.

The microstructure was studied on cross-sectionned samples by means of optical and scanning electron microscopy, after etching in appropriate reagents. Chemical composition homogeneity was investigated using EDS microanalysis. X-ray diffraction structure determinations were also carried out. 
The corrosion properties of the laser deposited 18-10 austenitic stainless steel clad layers have been tested by means of electrochemical techniques in four different aqueous saline media : deaerated $0.1 \mathrm{M} \mathrm{Na2SO} 4$ (neutral and $\mathrm{pH}=3$ ) and $30 \mathrm{~g} / \mathrm{l} \mathrm{NaCl}$ (aerated and deaerated). The tests were carried out on clad layers either in the as-produced conditions or after planing. For comparison, carbon steel and massive 304 stainless steel were also tested. Details about used techniques, sample preparation and experimental procedure have been published in [1].

\section{MICROSTRUTURAL CHARACTERIZATION}

The optical micrograph of figure 1 shows that the clad layers obtained had a uniform thickness and were free of cracks. They were also nearly free of porosities except sometime for cavities between adjacent overlapped tracks near the cladding / substrate interfaces, as shown on figure 2.

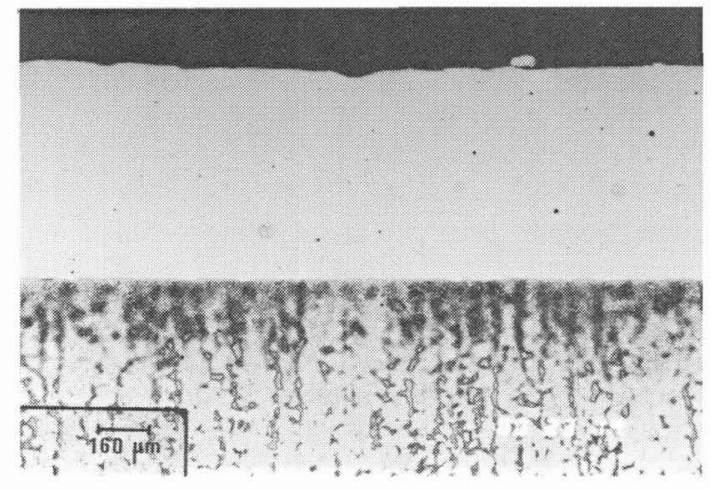

Figure 1 : Longitudinal-section optical micrograph of the clad layer ( $3 \%$ nital etching)

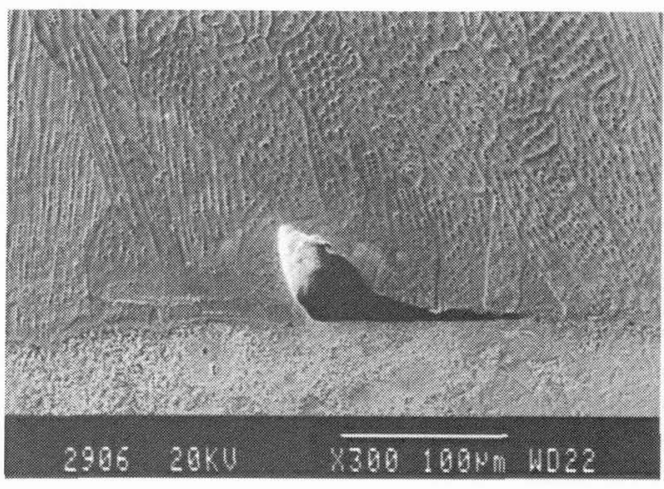

Figure 2 : Cross-section secondary electron image near cladding / substrate interface

The substrate was melted to a depth of less than $10 \mu \mathrm{m}$ in such a way that the dilution of the cladding material was almost zero. EDS chemical composition determinations, reported on table 1, show that the chemical composition of the clad layer is pratically the same as that of the injected powder, what confirms that the dilution was weak. Nevertheless, the metallurgical bonding between the clad and the substrate was very good. The concentration profiles for the main elements through a cross section of the clad layer are drawn on figure 3 . They show the correct iron, nickel and chromium homogeneity in the coating.

Table 1 : EDS Chemical composition measurements (weight \%)

\begin{tabular}{|c|c|c|c|c|c|}
\hline Analysis & $\mathrm{Fe}$ & $\mathrm{Si}$ & $\mathrm{Ni}$ & $\mathrm{Cr}$ & Balance \\
\hline powder 304 & 67.6 & 1.0 & 11.4 & 19.7 & 0.3 \\
\hline clad layer & 68.4 & 0.9 & 11.3 & 19.0 & 0.4 \\
\hline austenitic cells & 67.8 & 0.9 & 12.4 & 18.4 & 0.5 \\
\hline ferritic rich areas & 68.8 & 0.5 & 8.0 & 21.8 & 0.9 \\
\hline
\end{tabular}

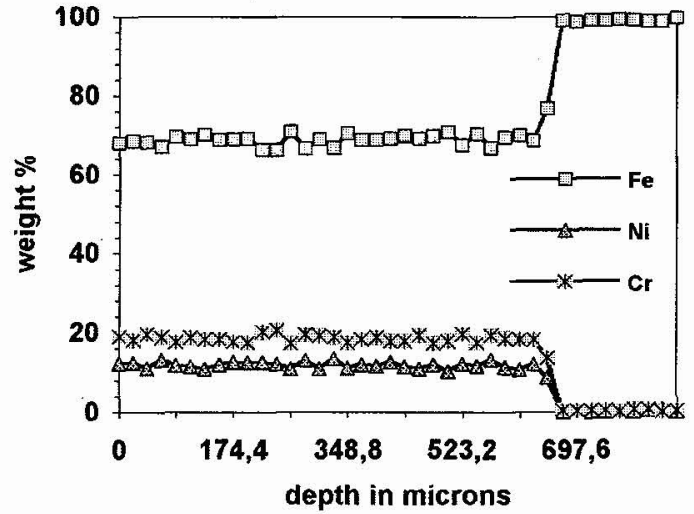

Figure $3: \mathrm{Fe}, \mathrm{Ni}, \mathrm{Cr}$ concentration profiles obtained through a cross section by EDS 
$\mathrm{X}$-ray diffraction analysis (figure 4) showed that the structure was mainly austenitic, with a low content of $\delta$-ferrite; it also revealed a texture effect for austenite, $\gamma(200)$ peak being higher than $\gamma(111)$ one. Metallographic investigations pointed out that the clad layer microstructure was dendritic or cellular with an interdendritic distance and a cell size of between 5 and $10 \mu \mathrm{m}$ as shown on figure 5 .

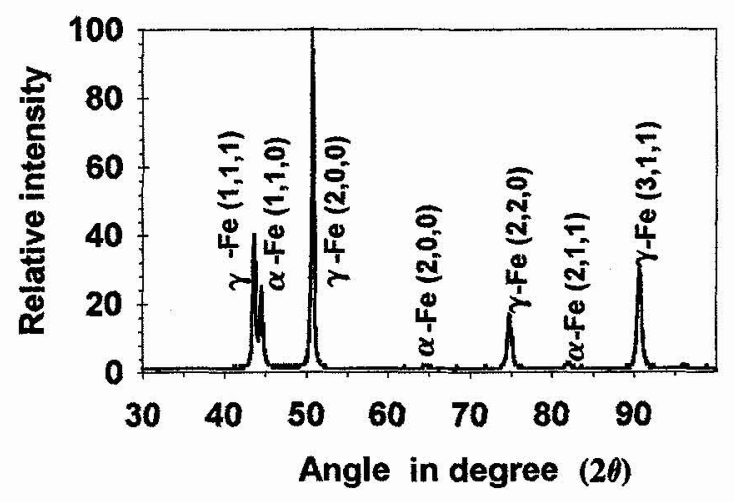

Figure 4 : X-ray diffraction pattern

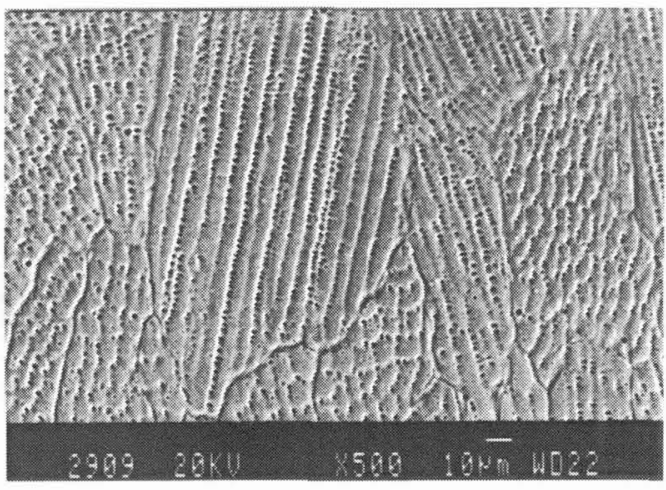

Figure 5 : Cross-section secondary electron image $\left(\mathrm{HCl}+4 \% \mathrm{H}_{2} \mathrm{O}_{2}\right.$ etching)

Dendrites and cells had an austenitic structure and it can be seen on figure 6 that $\delta$-ferrite has been formed at the end of the solidification in the intercellular spaces containing a higher chromium content as revealed by EDS microanalysis (table 1). Nevertheless $\delta$-ferrite was not uniformly distributed as shown on figure 7 . Indeed in each track, due to overlapping, a region is heat affected by the following deposit track, in such a way that an autenitisation occurs leading to a fully austenitic structure after cooling. Hence two different structures are observed on each side of the cladding / cladding overlapped interface (Fig. 7).
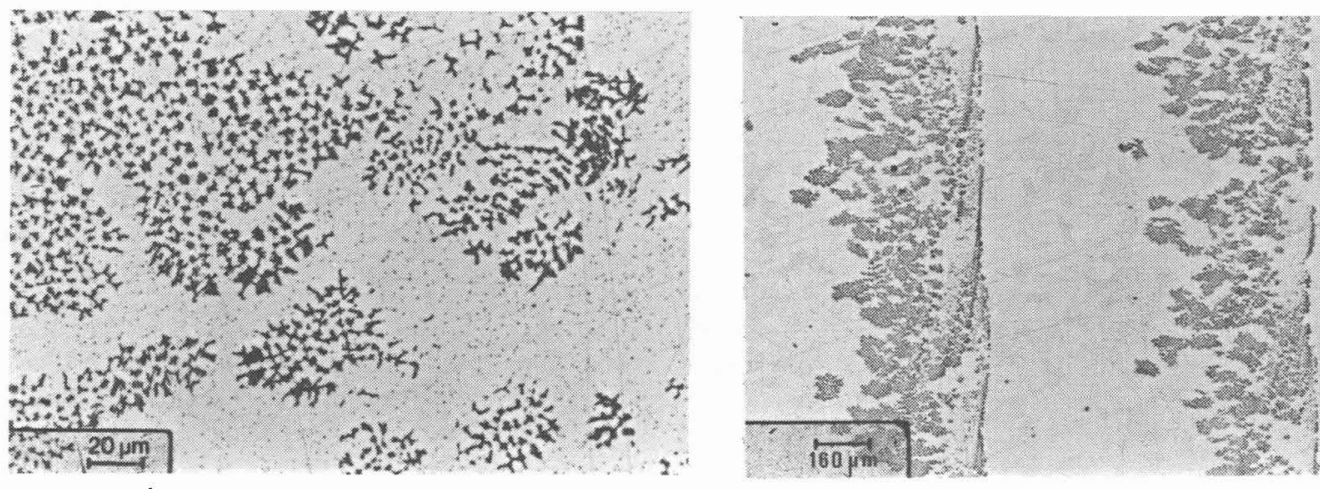

Figures 6 et 7 : Optical micrographs of the clad layer surface (Kalling reagent etching)

\section{CORROSION BEHAVIOUR RESULTS}

Table 2 summarizes the observed results in the various media and gives both the free corrosion potential Ecor, determined after stabilization, and the corrosion current density obtained by extrapolation of the polarization curves recorded at a $1 \mathrm{mV} / \mathrm{s}$ rate, after obtaining stabilized Ecor.

Table 2 clearly shows that the coated specimens present a corrosion resistance better than the substrate (mild steel carbon), and as good as massive 304 stainless steel, even better in case of immersion inside neutral aerated $\mathrm{NaCl}$ solution $(30 \mathrm{~g} / 1)$. This behaviour is even enhanced in case of surface polishing, the clad layer being thick enough to allow this post-treatment. The corrosion potential values are even more noble in this case, maybe due to the elimination of surface impurities, defects or chemical homogeneity lack. Indeed, the laser treatment leads to realize an overlapped coating. 
Table 2: Electrochemical measurements

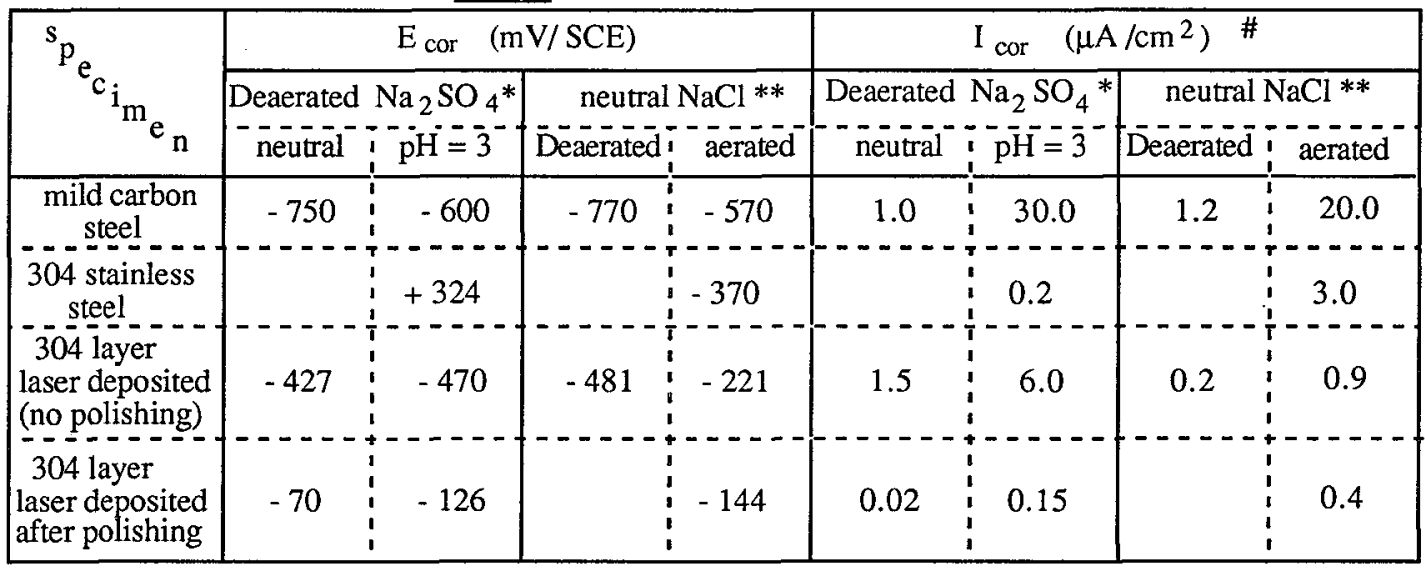

\# $1 \mu \mathrm{A} / \mathrm{cm}^{2}===>10 \mu \mathrm{m} /$ year $\quad * \mathrm{Na}_{2} \mathrm{SO}_{4} 1.0 \mathrm{~mol} . \mathrm{L}^{-1} \ldots * * \mathrm{NaCl} 30 \mathrm{~g} . \mathrm{L}^{-1}$

A long immersion test has been carried out in aerated $\mathrm{NaCl}$ solution with a clad 304 layer specimen without polishing. The results are given in table 3 . The Icor values are determined from polarization curves recorded only near the corrosion potential value $(-100$ up to $+75 \mathrm{mV} /$ Ecor) in order to prevent the risk of artificial corrosion. We can notice that the corrosion rate is very low during the whole immersion duration, even if the Ecor values become more negative.

Table 3: Electrochemical results of long immersion test

\begin{tabular}{|r|c|c|}
\hline & E cor $(\mathrm{mV} / \mathrm{SCE})$ & $\mathrm{I}$ cor $\left(\mu \mathrm{A} / \mathrm{cm}^{2}\right)$ \\
\hline at the immersion & -184 & 0.09 \\
after 24 h of immersion & -157 & 0.01 \\
after 32 h of immersion & -286 & 0.10 \\
after 48 h of immersion & -345 & 0.15 \\
\hline
\end{tabular}

\section{CONCLUSION}

The laser powder cladding technique allowed to produce 18-10 stainless steel clad layers with a good metallurgical bond with the substrate and a low level of dilution. These layers were sound, crack-free and with few porosities so that the corrosion properties could be tested. In every case, even in an aerated saline medium, the corrosion current densities were very low indicating an excellent uniform corrosion resistance, comparable to, or even better than, that of a massive stainless steel of the same type.

\section{REFERENCES}

[1] RENAUD L., FOUQUET F., MILLET J.P. and CROLET J.L., Surface and Coatings Technology 45 (1991) 449.

[2] HOADLEY A.F.A., FRENK A. and MARSDEN C.F., Proc. 1st Australia Int. Conf. on "Surface Engineering : practice and prospects" - Adelaïde, Australia, 12-14 march 1991.

[3]WEERASINGHE V.M., STEEN W.M. and WEST D.R.F., Surface Enginneering 3 (1987) 147.

[4] SINGH J. and MAZUMDER J., Metallurgical Trans. A 19A (1988) 1981.

[5]MARSDEN C.F., FRENK A., WAGNIERE J.D. and DEKUMBIS R., Proc. 3rd Europ. Conf. Laser Surface - Treatment of Materials, Eclat 90, Erlangen - Bergmann \& Kupfer Eds - (1990) 535.

[6]MARSDEN C.F., HOADLEY A.F.A., WAGNIERE J.D., Proc. 3rd Europ. Conf. Laser Surface Treatment of Materials, Eclat 90, Erlangen - Bergmann \& Kupfer Eds - (1990) 543. 